\title{
Ritual of ancestor Sacrifice and Social Function in the Veda and Thai People
}

\author{
Thanakorn Choosukhserm ${ }^{1}$, Prayong Saenpuran ${ }^{2}$, Phramaha Surawut Sangmano $^{3}$, \\ Phrakhruwinaithorn Worachat Thasa ${ }^{4}$, Phrasamu Kitphisit Jarphan ${ }^{5}$ \\ ${ }^{1}$ Faculty of Humanities, Mahamakut Buddhist University, Isan Campus \\ ${ }^{2,3}$ Faculty of Religion and Philosophy, Mahamakut Buddhist University, Isan Campus \\ ${ }^{4}$ Faculty of Social Sciences, Mahamakut Buddhist University, Isan Campus \\ ${ }^{5}$ Faculty of Humanities, Mahamakut Buddhist University, Isan Campus \\ thanakorn.cho@mbu.ac.th, ${ }^{3}$ Surawutsung@gmail.com, ${ }^{4}$ worrachat2519@gmail.com, ${ }^{5}$ j.kitty2011@ gmail.com
}

\begin{abstract}
The objectives of this academic article aimed to 1) to study the ritual of ancestor sacrifice in the Veda and Thai society and 2) to study the theories of folklore influenced toward the way of life of Vedic people and Thai society. The results indicated that the ritual or ceremony is a kind of activity and function in all human beings' society which related to and arranged by a doctrine, religion, or belief of tradition and culture for alchemy, supernaturalism or good fortune, etc. Ritual of ancestor sacrifice is a kind of belief in the Vedic period which is worshiped, performed, and continued from that time until the present. Vedic people believed in their ancestors' spirits and so did Thai people. Both people in the two nations believed that the ancestors' spirits could punish their relatives who had bad behaviors but help those who had good behaviors. Both nations have still believed that ancestors' spirits can provide them goodness and badness so they usually have to perform the sacrifices to the ancestors. Then, the ritual of ancestor sacrifice has become the deep belief of two cultures, unify, and create people to be a unique and happy society under their belief.
\end{abstract}

Keywords

Ritual, ancestor Sacrifice, and Social Function, the Veda

Article Received: 10 August 2020, Revised: 25 October 2020, Accepted: 18 November 2020

\section{Introduction}

The ritual of ancestor Sacrifice has been rooted in all societies of human beings since prehistory period until now. Most of the human beings have believed in ancestors' spirits, supernaturalism or animals' spirits, etc. This kind of belief is still settled in their deep minds and then reflected in the folklore, way of life and ritual of people in all societies. Ancestors' spirits came from the members of each family who died especially the grandparents or respected ones. Human beings have believed that dead grandparents will become the ancestors' spirits, and they can provide good, evil, prosperity or calamity to that family. Vedic people and present Indian people also have believed in ancestors' spirits, when some member in the family died, they would perform the sacrifice to those spirits. They were afraid that if they did not perform the sacrifice, the ancestors' spirits would not satisfy and could punish them to get undesirable things. So people in each period have to perform the sacrifice on the appropriate occasion. Thai people also have this kind of belief. Each year, they have to perform the sacrifice to dedicate some materials and goodness to their departed relatives or ancestors. The ritual of ancestor sacrifice of the two nations has been their functions which they have to do at the appropriate time and has become the driving force or impulsion to build unity and happiness in each society according to their belief.

\section{Ritual or ceremony}

Bidhikamma means ritual action that completes the wanted result or ritual action that leads the wanted action. It's the mutual activity of community, the tool that trained self- control or the basis to develop other virtues such as training the body and speech to be in self-control which causes to make happiness happen in that society. [1]

Bidhikamma is an activity, culture, tradition, and behavior that human beings supposed it up by intention according to their beliefs, has its steps in clear communication and action to attain the hope, happiness, abundance, rich, safety, and other objectives that one expected. [2] It is a way to create the fundamental discipline, support spiritual power to live together, living one's life and the beginning point to develop other virtues higher by the principle of Bidhikamma in that religion. It is the beginning point to train the body and speech to be in self-control to do religion or community activity together to reach the goal.

\section{The Vedas}

The Vedas scriptures, in the general meaning of Indian people, have not focused on alphabet terms but these have been inherited orally, and maintained in this character many thousands of years called "Oral literature." Furthermore, these scriptures were continued by many generations of Indian people by oral without any word changes. [3] Oral transmission about the story in the Vedas is very strict. Brahmins have believed that the Vedas are the Holy Scriptures, oldest books of Hindu literature called "Saruti" which means disclosure or revelation, hearing from the gods. The term "Veda" means knowledge or wisdom but the term "Riga" is the prose to praise the gods, so, when combined two terms, Rigveda, means the prose wisdom, primitive wisdom, has the holiest one of Aryan people and classifies into many groups of hymns to praise their gods. [4] The Vedas are divided into 4 scriptures: 1.) Rigveda is 
the scripture to collect mantras to praise the gods, has the priest pray mantras while performing the ritual. This scripture is believed the oldest one of Brahmins. 2) Yajurveda is the scripture mentioned about the rules of how to perform the sacrifice, ritual, and suggestions used in the Vedic sacrifice. 3) Samaveda, it is the scripture collected many kinds of poems prepared to pray in each time of ritual performing including the rhythm of praying in ritual performing. 4) Atharvaveda is the scripture that happened in the late period, and the collective source of mantras, spells, incantations, rules, or ways of using the black mantra and white mantra according to their objectives.

The Vedas are considered as the important sources of Indian civilization, literature, wisdom's storehouse and ancient ancestors' thoughts through many generations. Time and their experiences have preached and trained their thoughts to be concrete and developed to have 4 scriptures. The teachings of the Vedas are divided into 3 types: 1) Karmakanda means the practices for making merit, 2) Upasanakanda means meditation practice, and 3) Jyanakanda means spiritual knowledge to attain the gods.

\section{Theories of Folklore}

This theory explains the role of folklore, the way how to live in each society and culture of the people, myths and various genres of myths, the role of play as a story in the folk society, and it also relates to other types of cultural information to analyze interesting social conditions. [5]

This theory considers that other parts of cultures in society have a duty to be responsible for the needs of human beings on both sides; on the basis of social and psychological stability. In the part of folklore, different types of stories, songs, plays, beliefs, and rituals are responsible for human psychological needs and helping to strengthen culture in each society. Therefore, the cultural study of folklore should consider the social contexts to find or highlight the importance of information that helps a society to sustain itself stably. One key thinker, Bronislaw Malinowski, said, "The characters of the story are very important. But if they are no the contexts, they appear to be something inanimate ... The original stories live in the community society, but they are not alive on paper." [6]

Bascom explains that each type of folklore may have a different role, and some may have many roles, so he classifies different functions of folklore into 4 types: 1) It uses for the sources and reasons in performing the rituals, 2) It functions to educate in the telling society, 3) It keeps a standard of the custom behaviors of the society, and 4) It provides the amuses and way out of discomfort or anger to the person. [7] The Folklore theories according to Siraporn Nathalang's methodology in the analysis of myths and folklore described the 4 kinds of roles and duties of the folklore as Bascom wrote as a framework for presenting the roles and duties of folklore into 3 main kinds: [8]

1) The role of Folklore in explaining the origin and identity of community and rituals. Almost traditional societies do provide the importance of ritual performing, and it is found that traditional societies have many rituals in daily life such as the passage ritual, the new production ritual, the ritual worship of supernaturalism and the ritual of calendar in each month, etc. Then, traditional societies, and rituals have been become the matter of each community. The rituals are the unity of people in society. Each time of ritual performing causes to make the community's members having stable feeling, warm, and happy. So, the rituals are the mechanism to create the feeling of "the same group," and community's identity.

2) Roles of Folklore in education, social order training, and maintaining social behavior standards: In illiterate societies such as tribes' society, hill tribes' society including literate society but they still use tradition to tell a story in teaching the culture such as the society of Thai farmers. The folklore has been the important mechanism to function an "education institute" to teach the knowledge, culture, local wisdom, attitude cultivating, social order training, and maintaining the standards of morality and pattern behavior accepted by society reflected through many types of folklore namely; lullabies or cradle songs, tales, proverbs, riddles, plays or shows, etc. [9]

3) Folklore's role in finding out of personal grievances arising from social rules: The first two topics mentioned above may be considered that it is the role of folklore in society, but folklore also has a direct role; psychological role. It is because the folklore can offer "alternatives" that can compensate for what humans desire but cannot do in real life and also offer "solutions" to problems arising from the strict social rules which made the society members frustrated or being uncomfortable unable to speak or express when there is a conflict in their minds. Therefore, folklore has a direct role in presenting the spiritual "solution" to human beings in society, especially folklore in the genre of miraculous tales, tales, jokes, songs, singing and folk games. [10] Folklore, especially fairy tales with imaginations use symbols to represent social reality, society is therefore a social mechanism that extends "refuge" or a place where human beings can escape from the real world to temporarily stay in the world of fantasy (Escape in Fantasy). [11]

All of these ideas have shown that each type of folklore has different functions. Legends help to explain the identity of the people and explain the origin of each ritual. In a traditional society, the ritual is a very important cultural mechanism for building unity in the community and strengthening the people. Local fiction helps to build a feeling of attachment and familiarity with "their local." Moral stories, fables, stories about animals, nursery rhymes, proverbs, riddles, children's play are all involved in providing knowledge, cultivating values and training social order among members of society which is equal to Folklore has served as the "Educational Institutions" in a traditional society.

In summary, the theory of roles and functions of folklore in society is considered that elements of a culture such as system of belief and religion, family system, government system, educational system, recreation system, they all serve to help, provide the spiritual and social security. Many kinds of systems that are social or cultural mechanisms have their functions. It is comparable to organs in our bodies, they all have different functions that will make the bodies survive together. If any organ in the body is unable to function, it will have an impact on the health of the body, and so are various cultural systems. If they are able to perform their duties well, that society will live and operate well too. 
Therefore, it is said that roles of folklore are the part of the cultural system.

\section{Ancestor and sacrifice}

Ancestor means a person related to you who lived a long time ago, a person who is several generations earlier in an individual's line of descent. [12]

Edward Burnett Tylor, a British anthropologist, whose Primitive Culture (1871 developed the thesis of animism, a view that the essential element in all religion is the belief in spiritual beings. According to Tylor, the belief arises naturally from elements universal in human experience (e.g., death, sleep, dreams, trances, and hallucinations) and leads through processes of primitive logic to the belief in a spiritual reality distinct from the body and capable of existing independently. All things are believed to possess spirits that are their effective and animating elements; for example, primitive peoples generally believe that spirits cause sickness and control their destinies. Ancestor worship, prevalent in preliterate societies, is obeisance to the spirits of the dead. Fetishism, the veneration of objects believed to have magical or supernatural potency, springs from the association of spirits with particular places or things and leads to idolatry, in which the image is viewed as the symbol of a spiritual being or deity. [13]

Ancestor rituals according the Rig Veda and Atharva Veda (1200-1000 B.C.) include hymns for both inhumation burial and cremation, the verses telling about construction of marker of earth and rituals performed by mourners on behalf of both the living and the deceased. Later, Brāhman texts describe a Citi (mound) to be erected on the burning and burial ground as replica of the Agnicayana Shrauta sacrifice, a cosmic soma ritual that the deceased had performed with a thousand bricks to create an altar of fire and regenerate the world.

Vedic people believed the death and nurture of ancestors who concerned with the disposition of the body in Antyeshti, the "final sacrifice." People in this period believed that a new body awaited the deceased in heaven no longer prevailed, they had to do the ritual construction of a temporary body for the disembodied "Spirit" (Preta). It is a brief passage for entering the status of "ancestor." When the deceased became a Pitri in an otherworldly realm of ancestors, there would have ritual sacrifices to nurture that ancestor during all stages of advancement toward another rebirth. All of this proceeds from the doctrines of karma and Samsāra that emerged with a new worldview in the early Upanishads. These late Vedic texts distinguish between the Pitriyāna (path of ancestors), which leads to the moon, an abode from which the departed return to earth and a new existence, and the Devayāna (path of gods), which goes to the sun without return or rebirth. The moon retains an important cosmic role in ancestor rites today, as do the moral implications regarding the effect of action (karma) upon the fate of the deceased in rebirth (Samsāra). [14]

Ancestor worship or sacrifice of Hindu people called a ritual of Pinda offering or Sraddha ritual. This ritual has been performed from the ancient time [15] Hindu people have believed in this ritual that the dead and living people want the same necessary things. The dead wanted to have meal, drink water, and consume many things like living people at all. When someone died, it had only a body decayed by its nature but there is one thing still remains, not decay or die as like a body that is each one's spirit (Vinnana). Thus, the dead's relatives had to do this ritual when the family's members died.

Characteristic of Pinḍa like a small ball made of rice or meat mixing with milk, curd, and flowers. [16] Sometimes, ancestor worship was called "Pitriyajña." It is one of the great five sacrifices in the past. To perform this ritual is a duty of married son. He will perform it daily. Hindu people believed that a family leader or father regarded as a high Brahmin in family and a controller of the family's ancestor worship. He is believed that he is an expert and has knowledge of special ritual practiced continuously. Thus, it is his duty to care and nourish it without any changes and then teaches how to carry on this ritual for a son to train him to be a high Brahmin instead.

In the present, Hindu people approximately two-three hundred thousand like going to perform Sraddha ritual at Gayasisa villadge, Buddhagaya sub-district. They have believed that dead cremation is Avamonggala but Sraddha ritual is Monggala. Moreover, they have believed that when someone died, a physical body only was died, this corpse will be burned at all but a dead spirit still remains in a state of jinn, ghost or Preta and circulates or goes around its cremation place. Ones cannot go anywhere because one does not have the body, feeling, it causes to make him or her lack of internal sense-fields or external sense-fields in perception. They have believed that spirit of a departed in the jinn condition, unpurified and always worries about many things. Relatives had to perform some ritual first, a dead's spirit would have rebirth.

Thus, to purify unpurified condition of a jinn or ghost, the relatives have to perform Sraddha ritual for the departed after ones died 10 days by building the Rupa or body for the jinn to be possessed called "Sukhuma rupa or subtle body." The Jinn or Preta will dwell this subtle body going to own appropriate sphere or existence whether it will be heaven or hell. So after died 1 day, a dead's relatives would offer Piṇua rice or sticky rice molded as a small ball, placed on a container or banana leaf with rice and variety of desserts.On the second day, the relatives would perform the sacrifice like the first day by believing that Pinda rice and many foods prepared by relatives would rebuild the sense-fields: eyes, ears, and tongue, for the ghost or Preta to make him have feeling or emotion.

On the third day, the relatives performed the same sacrifice. They believed on this day that food would become an energy to build a neck, shoulders, arms, chest and other organs according to a number of the sacrificial days performed. On the ninth day, the jinn or Preta will have a complete body and on the tenth day, it will have hair, beard, and nails and he will become Pitri or ancestor. Then, his skin color or complexion will become bright or pure and finally an angel or deity. Sraddha ritual has another name "Pitriyajna" which means to worship the departed ancestor. This ritual has been performed before a religious system happened. It has appeared that almost group of people in this world has been performed this ritual in their houses or sanctuaries. The mantras used in this ritual is Samaveda.

On the eleventh day after died, there is the great Sraddha. The relatives began a ritual by pouring water to dedicate 
goodness to a dead, imploring or pleading the deity such as Visnu come to accommodate for the jinn or Preta. Hindu people believed that by doing this way, a dead could cross the great flood of Samsara. Here are some Vedic verses mentioned about ancestors and ritual:

“...'With offspring, with increase of wealth', he says; verily he abides in this world with offspring and with cattle. 'Homage to the gods', he says, for homage is the due of the gods; 'svadhá' to the Pitrs', he says, for the svadhá call is the due of the Pitrs." [17]

"...1 May the Vasus, with the Rudras, protect thee on the east; may the Pitrs whose lord is Yama, with the Pitrs, protect thee on the south; may the Adityas, with the Allgods, protect thee on the west; may Dyutana Maruta, with the Maruts, protect thee on the north [4]; may the gods, whose chief is Indra, protect thee from below and from above..." [18]

Vedic Pitriyajya was the ritual to dedicate good things for the departed in order to express the relatives' remembrance or mournfulness, love, relationship, unity, and gratefulness towards the parents, siblings and relatives. This ritual had been since the human beings lived in the cave and were developed respectively according to the traditions, cultures, and community's belief.

\section{Ancestor and Sacrifice in Isan Region}

Thais in northeastern region or Isan has believed in Supernaturalism and Animism for a long time like many Thais in other regions. This kind of belief has inherited from their ancestors and has influenced toward the way of life of Isan people for a long time before they accepted Buddhism as their refuge in the present. In the past, Isan people believed in the natural spirits, gods, goddesses, ghosts, holy thins or sacred items and belief of Thaen etc. Jit Phumsak said that the primary religion of Thai race is Animism. They had believed that the gods or Devatas were their ancestors and inherited from Thaen god. In the present, the current of this thought has changed gradually because of new development and technology but its trace has been appeared in many forms of traditions and rituals in many areas of Isan region such as rocket festival, dance for Pheepha or Pheethaen (dace for aerial gods to cure some diseases) or ritual of morale making etc. [19]

Sisak Wallipodom pointed out that spirit belief in Thai society has been a long time and affected on social being and psychology. Tradition of spirit belief in Thailand has related to Buddhism and Hinduism from the past until now. This belief is not only limited by a dead but it is covered to other environments which believed that it's holy and supernatural power such as earth, sky, rivers, mountains, and trees. [20] Although most of Thai people have believed in Buddhism but it still has an interpolation and blending of spirit belief among religion such as when people made merit, they have to pour ceremonial water for dedicating goodness to the dead and ancestors.

The research result entitled "Phipakam : the belief in ancestor spirits of Thais-Kouy (Soai) in Surin province," found that Phipakam is spirit haunted in Pakam skin (lasso for hooking a wild elephant). Local people have believed that there are 2 kinds of spirit: Phragru is a holy spirit which had status similar to deity and ancestor spirit in lineage of elephant-fed family or mahout. They have believed that Phipakam can give both benefits and disadvantages to human beings. So they do always sacrifice to this spirit. This belief is not limited in the Kuay group only but it can be found in general people performed this career. Phipakam is not only the spirit haunted in lasso for hooking an elephant but it empowers greatness and safety of life to devotees. [21] Isan people in each area have belief in ancestors' spirit differently in details. Most of family has to perform the sacrifice to their ancestors every year on the appropriate time because they are afraid that if they do not perform the ritual or sacrifice for the ancestors, they will be punished and do not get all benefits in their life. This kind of belief still remains in life of Isan people now.

\section{Ancestor and Sacrifice in Northern Region}

From a long history of Lanna people, they have believed in spirits many hundreds years ago. Its history mentioned that local tribe called "Luah" had lived around the hill area of Doi Sutheb before the king Mangray established Chiang Mia city on BE 1839. Lanna people and their belief of spirits could not separate clearly. In the present time, there have been a mixture of two cultures: local hill tribe and new comers. Their spirits' belief does not have much intensity like the past time. But most of people in this region still have had belief of ancestors' spirit and ceremony of sacrifice. This belief has more influence to the way of daily life which has seen from their custom, tradition many ceremonies of northern people such as when they go to the temples, whey will separate meals into 2 parts; one for the monks and another for sacrificing the ancestor's spirits. They have believed in many kinds of spirits because each spirit has different duty such as ancestors' spirits have a function to protect the relatives and family; Phi-arak or areas' spirits has a function to protect the community, village and city, etc.

When Lanna people have some activity to do or take a rest in the forest they always have to ask for permission from the spirits first or when they have meal in the forest, they will also offer food to the spirits or when they have to excrete or urinate in the forest they have also to ask for permission from the spirits. [22] These things have reflected the way of life of Lanna people mostly related to many spirits. So they have to perform a sacrificial ceremony on the month 4-8 every year. On this time, most of villages in the northern region perform a ceremony of ancestor worship such as Chiang Kham district of Phayao province perform the sacrifices to Phisueban, Phisuemuang or ancertors' spirit, Philuah, Phimod, Phimeng, Phipusae and Phiyasae, etc. [23] The ceremony of ancestors' worship and sacrifice including other spirits of Lanna people have two main purposes: the first is to ask for a good health for the members of families, and the second is to ask for the protection from the ancestors' spirits and other spirits to take care all people in the community. So they have to perform the ceremony of sacrifice to the ancestors and other spirits every year. Now many people think that belief of ancestors' spirits and sacrifices are changed by new world and technology but we've still met a trace of this belief in many rural villages which called 'Horcauti or a cottage of the village's guardian spirits.' 
Spiritualism of Lanna people might get a trace from ancestor worship in the past time. This belief has been grown up from animism of human beings around the world back to many thousand years ago in the ancient time. The animism is the primary source of spiritual belief and some religions. Anthropologists have determined this belief as the religion of pre-historical and historical societies. This belief still has still remained in many traditions and human beings' behaviors in almost societies. It seems that this kind of belief is still the co-characteristics of Tai-tribes or Lanna people. The spiritualism of Lanna people is the primitive belief before Buddhism was spread in this region. The perspective of Lanna people understood that human beings' world and spirits' world were complicated and related with each other. They have believed that spirits are in everywhere such as in the cities, villages, paddy fields, rivers, water, forests, mountains including houses, etc. These spirits can provide benefits and punishments to people, so they have to perform the ceremony of ancestor worship and other sacrifices every year to satisfy them. If someone has bid and inappropriate behavior, he or she will lose the benefit or get bad luck, so spirit has both a good and bad part able to build poverty and prosperity to everyone. This belief causes to make lots of benefits as follows: [24]

1. It is mental refuge. The northern people like to praise the old relatives or seniors. When they died, the successors have to set up a joss house for their spirits. When there has some problem in family, they have to worship and sacrifice to ask for help.

2. It is time to collect the near and far most relatives to meet and talk to each other.

3. It is time to introduce a future member to a family such as bride or bridegroom.

Lanna people and belief of ancestors' worship including performing the sacrifices to the spirits have reflected the primary belief of people in this region many hundreds of years ago. There are many tribes and ethnicities of local people in this region such as Taiyai, Taikhern, Taileu, Taiwon or Lanna people etc. All groups have believed in spirits, these spirits are in the way of life and everywhere. It is primary belief before Buddhism came to this region. They believe in spirits because these spirits can provide them both goodness and badness, so they have to perform the annual ceremony for ancestor's worship and spiritual sacrifices. This belief has reflected many reasons such gratefulness, harmony, and respect of natures and environments. Human being should not forget the ancestors' favors and natures.

\section{Ancestor and Sacrifice in Southern Region}

Thai society in the northern region has believed in supernaturalism, animism, gods, goddesses, and spirits like many regions of Thailand. This belief has gotten an influence from religion and mixed with local belief. [25] Local people have believed that many kinds of natures have invisible spirits behind, have more influence than themselves. These spirits can inspire them both prosperity and loss. This belief has been in the southern local people such as people in Hoi-khong district. They do still have the Wai-ritual of Ta-yay (grandparents worship or sacrifice). This ritual is the local wisdom to create an experience of living, rely on belief of ancestors' spirits, virtues of departed relatives to build the social power, unique and unity to the members of each family. [26]

One of most important rituals is Sarda in Nakorn $\mathrm{Si}$ Thammarat province. It is usually performed on the lunar month, on the waning moon 1-15 of the 10th lunar month. But people in Nakorn Si Thammarat province usually like to do this merit on 13-15 of lunar month. People in this region have believed that the ancestors namely: grandmother, grandfather, and departed relatives, if they did bid they would go to hell, become Preta, get suffering in hell for a long time, and have to rely on merit's result that descendants dedicated to live. So, on the first day of the lunar waning moon, sinners that called "Preta" were released from hell to the human beings' world to ask for good or merit from their descendants, and they would come back on the waning moon 15 of the 10th lunar month. The essence of this is as follows:

1. It notifies gratitude towards the departed ancestors trained descendants how to live in the present so they have to repay the done favor by dedicating merit to them.

2. It is a chance to unify the remote relatives, meet each other to make merit, and create intimate love among relatives.

3. It is time to make merit in a chance of agricultural products producing its results because it is believed that it is good and prosperous to ones and family.

Two rituals above represented that Southern people have believed in ancestors' spirits for a long time before Buddhism spread in this area. When the members in each family died, their bodies were cremated or buried on local tradition, religion or belief, but they still believe that it remains something, not cremated like physical bodies; their spirits especially grandparents' or respectful spirits. These spirits can give them good luck or all kinds of prosperity if the family's members have good behaviors, but bad luck or all kinds of ruins if they had bad behaviors, do not pay attention or ignore family's ritual or ceremony.

\section{Ancestor and Sacrifice in Central Region}

Local villagers called "Thai Song" in many districts of Nakhon Pathom province believed in their ancestor spirits for a long time and became dominant identity of this community. Most of local villagers have still believed in ancestor spirits strictly. Every family has to build a shelf for household spirit, perform "Padtong" ritual every determined day. The sons, daughters, and children in each family have to follow their belief, perform a ritual, and continue this belief until the present. [27] According the great scholar of Thailand, Sathaingoset, he divided Phee into 2 kinds: 1) natural ghost, it occurred from spirit of a unit of the universe gods and goddess etc., and 2) ghost or Phee occurred from spirit of a departed one in each family.

It could be both common ghost and bad ghost able to give both benefit and blame or punishment. [28] Everyone pays respect and follows traditions and ritual about ancestor spirits severely. They have believed that the ancestor spirits could provide them both benefit and blame or punishment. When one practiced well, Phee or spirit would give one's benefit. When ones practiced badly, did something wrong or violated good tradition of community, it would give a 
punishment. When spirit gave benefit, one has to reward or repay by offering foods and water. [29]

People in the center region of Thailand have also believed in spirits for example "Thai Mon." Mon people like to call spirit as Pheemon. It means family spirit or primary spirit of each family that they pay respect or believe for a long time. [30] They have to perform the sacrificial ritual for family spirit 1-2 times every year according to the way of life in the community. When they have the family's sacrificial ritual in family, they have to follow; 1) prohibit to do the sacrificial ritual on Buddhist holiday or Wanpra and other days, and 2) prohibit to do the sacrificial ritual on the Buddhist Lent festival, each family has to perform it on the even months; month 6 or 12 .

A performer is called "Tong" not limiting sex and age, has to understand how to do every step in this ritual according to the continued right belief. Every Mon community has a ritual performer. He performs the ritual to cultivate, build conscious mind of gratitude toward his or her ancestor's spirit and importance of family's spirit. In each performing the ritual, Mon people have to follow their belief and old culture that their ancestors have been inherited a long time unchangeably which cause to make self-respecting in identity of Mon ethnicity. This kind of ritual causes to make harmony and unity in every family, reflects the way of life and belief, and can control the behavior of people in community going on their old practices rightly.

Mon people have believed that the family's spirits do always take care of and protect their sons and daughters from all kinds of dangers. Family's members have to respect the spirits, perform the sacrifice ritual strictly. Every year, everyone in each family has to do the sacrifice to their ancestors. The important idea is as follows: 1) This ritual has a role to cultivate popularity of gratitude toward the deceased ancestors. 2) It can cultivate popularity of monogyny that will be seen in the steps of ritual. 3) It can cultivate the right social manner or behavior when ones have to stay or take a rest in another family. Mon teenagers should not tease each other in house area and a wife and husband should not make intercourse in other family.

\section{Discussions}

When we considered all details mentioned above, we found that Thai people in all regions have believed in ancestors' spirits before Buddhism spread in this country. In each region and ethnicity, they will perform the ritual of ancestor sacrifice differently. Their sacrifices may be food, dessert, clothes or necessary things according to their belief in each place. Every year, they will find the appropriate occasion to do the sacrifice for their ancestors' spirits. When they got the good day, they will invite their relatives from another place to do this ritual together. If someone could not come, he or she has to send some money to support this ritual. It has reflected that this ritual is the good way to cultivate gratitude, system of monogyny and right social behavior in their family and community, and it could teach the family's member how to live together happily.

\section{Conclusion}

The results indicated that the ritual or ceremony is a kind of activity and function in all human beings' society which related to and arranged by a doctrine, religion or belief of tradition and culture for alchemy, supernaturalism or good fortune etc. Ritual of ancestor sacrifice is a kind of belief in the Vedic period which is worshiped, performed and continued from that time until the present. Vedic people believed in their ancestors' spirits and so did Thai people. Both people in two nations believed that the ancestors' spirits could punish their relatives who had bad behaviors but help them who had good behaviors. Both nations have still believed that ancestors' spirits can provide them goodness and badness so they usually have to perform the sacrifices to the ancestors on the appropriate time every year. Then, the ritual of ancestor sacrifice has become the deep belief of two cultures, reflected unity, and created the social functions to people to be unique and happy society under their belief.

\section{References}

[1] Phra Dhammapitaka (P.A. Payutto), “Ceremony isn't Important?". Bangkok: Kledthai, p. 7, 2537.

[2] Th. Choosukhserm, 2562). "An Analysis of Rites in the Vedas", Doctor of Philosophy Program in Eastern Philosophy and Religion, Graduate School, Khon Kaen University, 2562.

[3] S.W. Jamison and M. Witzel. Vedic Hinduism. N.P., 1997.

[4] Griswold, H.D. The Religion of the Rigveda.Delhi: Motilal Banarsidass. p. 54, 1999.

[5] Siraporn Nathalang. Theory of Folklore: Methodology in Local Thai Folktales Analysis. n.d., p. 317, 2548.

[6] Malinowski, B. Magic, Science and Religion. Garden City, New York: Doubleday. p. 104, 1954.

[7] Bascom, W.R. Four Functions of Folklore. The Study of Folklore. New Jersey: Prentice Hall. pp. 281-298, 1965.

[8] Siraporn Nathalang. Theory of Folklore: Methodology in Local Thai Folktales Analysis. n.d., pp. 320-368, 2548.

[9] Theory of Folklore: Methodology in Local Thai Folktales Analysis. n.d., pp. 341-347, 2548. 
[10] Folklore in Windows' pictures of Watphrachetupon Church. Bangkok: Bangkok Publisher. pp. 350-351,2543.

[11] Bascom, W.R. Four Functions of Folklore. The Study of Folklore. New Jersey: Prentice Hall. pp. 290-291, 1965.

[12] Merriam-webster. Merriam-webster Dictionary. "Ancestor", Retrieved on 16th January 2021,from https://www.merriamwebster.com/thesaurus/ancestor

[13] Edward Burnett Tylor, Primitive Culture, Volume 2, London: Cambridge UniversityPress. pp. 108-109, 1871.

[14] Edward Burnett Tylor. Religion and Culture. First Published. London: 2017.

[15] Encyclopedia. "Hindu-ancestor-rituals." Retrieved on 16th January 2021, from https://www.encyclopedia.com/internation $\mathrm{al} /$ encyclopedias-almanacs-transcriptsand-maps/hindu-ancestor-rituals

[16] Samak Buravas. Brahmanism Philosophy in Buddhist Era. Second Edition. Bangkok: Siam Publisher. pp. 54-55, 2554.

[17] Clayton, A.C. (1913). The Rigveda and Vedic religion. London and Madras: Christian Literature Society for India. p. $101,1913$.

[18] Four Vedas: Rik, Yajus, Sama and Atharva, English Translation. n.d. Prapathaka III.The Exposition of the Soma Sacrificevi. 3. 3. p-1068

[19] Rik, Yajus, Sama and Atharva, English Translation. n.d. Prapathaka III. The Exposition of the Soma Sacrifice v. 5. 9. P 1008.

[20] Jit Phumsak. Beautiful Dream with Perfect Poetry 2489-2509. Bangkok: p. 120, Dokya, 2524.

[21] Sisak Wallipodom (Compiler). Spirit Belief in Thailand: Art and Culture, Bangkok: n.p.,p. 8, 2527.

[22] Sommai Chinnak. Pripakam : The Belief in Ancestor Spirits of Thai-kouy (Soai) Mahout Surin province. A Thesis for the Degree of Master of Arts in Sociology and
Anthropology. Graduate School. Chulalongkorn University., abstract. 2539.

[23] Cakrapong Kamboonraung. Lanna People and Belief of Spirit Sacrifice. Retrieved on 4th February 2562, from https://www.chiangmainews.co.th/page/arc hives/907432/

[24] Komnet Chetthaphatanawanich (Editor). Local Belief of Lanna. Social ResearchInstitute of Chiang Mai University, 2540.

[25] Manee Phayomyong. 12 months Tradition of Thai Lanna. Chiang Mai: S. Sab Publication, 2537.

[26] Suthiwong Phongphaiboon. Encyclopedia of Southern Cultures Vol.2. Bangkok: Krungsiam Publisher, 2529.

[27] Surichai Hwankaew and Kanokpornpan Ucha. Contemporary art and culture on diversityand confusion. Bangkok: Institute of Asian Studies, Chulalongkorn University. pp. 45-47, 2552.

[28] Thai Song in Siam Country. n.p. p. 59, 2538.

[29] Sathaingoset. Basic Culture. 6th Edition. Bangkok: Royal Society. p. 32, 2515.

[30] Boonmee Parichartthanakul. Belief of Spirit in the Ritual of Thai Song, Ban Phaihoochang, Banglen District, Nakornpatham province. Bangkok: Ramkhamhaeng University. p. 2, 2546.

[31] Kasak Tekhanmak. Constitute of Mon Spirits. Nonthaburi: October Press. p.5, 2561. 